Research article

Open Access

\title{
Genetic variation in stromal proteins decorin and lumican with breast cancer: investigations in two case-control studies
}

\author{
Linda E Kelemen¹, Fergus J Couch², Shahana Ahmed ${ }^{3}$, Alison M Dunning ${ }^{3}$, Paul DP Pharoah³, \\ Douglas F Easton ${ }^{3,4}$, Zachary S Fredericksen ${ }^{5}$, Robert A Vierkant ${ }^{5}$, V Shane Pankratz ${ }^{5}$, \\ Ellen L Goode ${ }^{5}$, Christopher G Scott ${ }^{5}$, David N Rider ${ }^{5}$, Xianshu Wang ${ }^{2}$, James R Cerhan ${ }^{3}$ and \\ Celine M Vachon ${ }^{5}$
}

\begin{abstract}
${ }^{1}$ Department of Population Health Research, Alberta Cancer Board, 1331 29th Street NW, Calgary, AB T2N 4N2, Canada 2Department of Laboratory Medicine and Pathology, Mayo Clinic College of Medicine, 200 First Street SW, Rochester, MN 55905, USA ${ }^{3}$ Cancer Research UK, Department of Oncology, Strangeways Research Laboratory, University of Cambridge, Worts Causeway, Cambridge CB1 8RN, UK

${ }^{4}$ Department of Public Health and Primary Care, Strangeways Research Laboratory, University of Cambridge, Wort's Causeway, Cambridge CB1 8RN, UK

${ }^{5}$ Department of Health Sciences Research, Mayo Clinic College of Medicine, 200 First Street SW, Rochester, MN 55905, USA

Corresponding author: Celine M Vachon, vachon@mayo.edu

Received: 30 Jul 2008 Revisions requested: 13 Oct 2008 Revisions received: 10 Nov 2008 Accepted: 26 Nov 2008 Published: 26 Nov 2008

Breast Cancer Research 2008, 10:R98 (doi:10.1186/bcr2201)

This article is online at: http://breast-cancer-research.com/content/10/6/R98

(C) 2008 Kelemen et al.; licensee BioMed Central Ltd.

This is an open access article distributed under the terms of the Creative Commons Attribution License (http://creativecommons.org/licenses/by/2.0), which permits unrestricted use, distribution, and reproduction in any medium, provided the original work is properly cited.
\end{abstract}

\begin{abstract}
Introduction The stroma is the supportive framework of biologic tissue in the breast, consisting of various proteins such as the proteoglycans, decorin and lumican. Altered expression of decorin and lumican is associated with breast tumors. We hypothesized that genetic variation in the decorin $(D C N)$ and lumican $(L U M)$ genes may contribute to breast cancer.
\end{abstract}

Methods We investigated associations of 14 common polymorphisms in the DCN and LUM genes with 798 breast cancer cases and 843 controls from Mayo Clinic, MN, USA. One polymorphism per gene with the strongest risk association in the Mayo Clinic sample was genotyped in 4,470 breast cancer cases and 4,560 controls from East Anglia, England (Studies of Epidemiology and Risk Factors in Cancer Heredity (SEARCH)).

Results In the Mayo Clinic sample, six polymorphisms were associated with breast cancer risk $\left(P_{\text {trend }} \leq 0.05\right)$. The association with LUM rs2268578, evaluated further in SEARCH, was positive, although the odds ratios (OR) were weaker and not statistically significant. ORs were 1.4 (95\% confidence interval [Cl], 1.1 to 1.8 ) for heterozygotes and 2.2
(95\% Cl, 1.1 to $4.3 ; P_{2 \mathrm{df}}=0.002$ ) for homozygotes in the Mayo Clinic sample, and were $1.1(95 \% \mathrm{Cl}, 0.9$ to 1.2$)$ for heterozygotes and $1.4\left(95 \% \mathrm{Cl}, 1.0\right.$ to $2.1 ; P_{2}$ df $\left.=0.13\right)$ for homozygotes in the SEARCH sample. In combined analyses, the ORs were $1.1(95 \% \mathrm{Cl}, 1.0$ to 1.2$)$ for heterozygotes and $1.6\left(95 \% \mathrm{Cl}, 1.2\right.$ to $\left.2.3 ; P_{2 \mathrm{df}}=0.005\right)$ for homozygotes. Positive associations for this polymorphism were observed for estrogen receptor-positive tumors in both the Mayo Clinic sample (OR for heterozygotes $=1.5,1.1$ to 1.9 and OR for homozygotes $=2.5$, 1.2 to $5.3 ; P_{2}$ df $=0.001$ ) and the SEARCH sample (OR for heterozygotes $=1.0,0.9$ to 1.1 and OR for homozygotes $=1.6$, 1.0 to $\left.2.5 ; P_{2 \mathrm{df}}=0.10\right)$. In combined analyses, the ORs were $1.1(95 \% \mathrm{Cl}, 0.9$ to 1.2$)$ for heterozygotes and $1.9(95 \% \mathrm{Cl}, 1.3$ to $\left.2.8 ; P_{2 \mathrm{df}}=0.001\right)$ for homozygotes.

Conclusions Although LUM rs2268578 was associated with breast cancer in the Mayo Clinic study, particularly estrogen receptor-positive breast cancer, weaker and modest associations were observed in the SEARCH sample. These modest associations will require larger samples to adequately assess the importance of this polymorphism in breast cancer.

CGEMS: Cancer Genetic Markers of Susceptibility; DCN: decorin gene; 2 df: two degrees of freedom; ER, estrogen receptor; LUM: lumican gene; MAF: minor allele frequency; SEARCH, Studies of Epidemiology and Risk Factors in Cancer Heredity; SNP: single nucleotide polymorphism; UTR: untranslated region. 


\section{Introduction}

Stromal changes are well documented in breast tumors [1,2] and in preinvasive breast lesions [2,3], and are hypothesized to play a role in breast cancer. The stroma may lead to morphologic changes that manifest as tumors through a stromal reaction or perturbation of epithelium [4] or, conversely, may play an initial landscaping role in tumorigenesis independent of epithelial neoplastic alterations [5].

The stroma is the supportive framework of biologic tissue consisting of an extensive extracellular matrix that supports cells, separates tissues and regulates intercellular communication. The extracellular matrix is composed of different proteins: decorin and lumican are members of the small leucine-rich proteoglycan family of proteins and are involved in matrix assembly and structure, and in the control of cell proliferation [6]. Knockout mice deficient for either the decorin (DCN) gene or the lumican (LUM) gene are viable, but show skin fragility, marked reductions in tensile strength and loosely packed collagen fibers with abnormal sheath diameters $[7,8]$ - implicating the small leucine-rich proteoglycans as major regulators of collagen fibril assembly that probably play a role in the development of a barrier against cell penetration and infiltration of macromolecules [6].

Recent evidence supports an anti-oncogenic role for decorin. Injection of decorin protein into mammary carcinoma rodent models resulted in a marked reduction in both primary tumor growth and metastatic spread compared with animals injected with vehicle alone [9]. Low levels of decorin protein in invasive breast cancers have also been associated with larger tumor size, shortened duration to progression and poor outcome [10]. The role of lumican in carcinogenesis has been less well studied. Immunohistochemical analyses of breast tissue detected significantly higher lumican protein expression in tumors than in adjacent normal tissue, yet significantly lower decorin protein expression in tumors than in normal breast tissue [11]. Positive associations between decorin and lumican protein expression and mammographic density, a major risk factor for breast cancer, have also been observed [12]. These findings suggest that expression and/or activity of members of the small leucine-rich proteoglycan family may affect breast cancer risk.

Given the role of the stroma in breast cancer [1,2], the occurrence of genetic alterations in the stroma of breast tumors [1315] and the putative contribution of decorin and lumican to this disease $[10,11]$, we hypothesized, a priori, that common genetic variation in the $D C N$ and $L U M$ genes is associated with breast cancer risk. We evaluated this hypothesis using data from a clinic-based case-control study of breast cancer, with follow-up in a large British case-control study.

\section{Materials and methods Mayo Clinic study design and population}

The Mayo Clinic Breast Cancer study is an Institutional Review Board-approved, ongoing clinic-based case-control study initiated in February 2001 at Mayo Clinic, Rochester, MN, USA. The study design has been presented previously $[16,17]$. Clinic attendance formed the sampling frame for Mayo Clinic cases and controls.

Consecutive cases were women aged 18 years or older with histologically confirmed primary invasive breast carcinoma who were recruited within 6 months of their date of diagnosis. Women with a history of cancer (excluding nonmelanoma skin cancer) were ineligible. Cases lived in the six-state region that defines Mayo Clinic's primary service population (Minnesota, lowa, Wisconsin, Illinois, North Dakota and South Dakota). Although Mayo Clinic is widely perceived to be a specialty tertiary care facility, it also provides primary care for over 500,000 individuals per year.

Control individuals without prior history of cancer (other than nonmelanoma skin cancer) were frequency matched on age (5-year age category), race and six-state region of residence to cases. Controls were recruited from the outpatient practice of the Divisions of General Internal Medicine and Primary Care Internal Medicine at Mayo Clinic, where they were seen for routine medical examinations.

Written informed consent was obtained from all participants. Case participation was $69 \%$ and control participation was $71 \%$. The present investigation genotyped Caucasian women (99\% of study participants) enrolled up to 30 June 2005, representing 798 cases and 843 controls.

Both the cases and controls completed a self-administered questionnaire comprised of known or suspected breast cancer risk factors, and they provided blood samples from which genomic DNA was isolated using the Gentra AutoPure LS Purgene salting out methodology (Gentra, Minneapolis, MN, USA). Quantities of $250 \mathrm{ng}$ genomic DNA were adjusted to $50 \eta \mathrm{g} / \mu \mathrm{l}$ before genotyping and were verified using the PicoGreen dsDNA quantitation kit (Molecular Probes, Inc., Eugene, OR, USA). The samples were bar coded to ensure accurate and reliable sample processing and storage.

\section{SNP selection, genotyping and quality control}

All SNPs in the $D C N$ and $L U M$ genes within $5 \mathrm{~kb}$ of the largest cDNA isoform (genome build 35) were selected from the Caucasian samples within the HapMap Consortium's release 21 [18]. We applied the IdSelect program [19] to bin SNPs with minor allele frequency (MAF) $\geq 0.05$ and pairwise linkage disequilibrium threshold of $r^{2} \geq 0.80$. tagSNPs were selected from these bins that met the criteria for predicted likelihood of successful genotyping using the Illumina GoldenGate Assay ${ }^{\mathrm{TM}}$ quality score metrics (Illumina Corporation, San Diego, CA, 
USA). We also included all putative functional SNPs (within 1 kb upstream, 5' UTR, 3' UTR or nonsynonymous) with MAF $\geq$ 0.05 identified in Ensembl version 34 (Ensembl, European Bioinformatics Institute/Wellcome Trust Sanger Institute, Wellcome Trust Genome Campus, Hinxton, Cambridgeshire, UK). Eight SNPs in DCN (including six functional SNPs) and six SNPs in LUM (including three functional SNPs) were identified and examined in the Mayo Clinic study based on these two methods of selection.

The DCN and LUM SNPs were assayed at Illumina Corporation (San Diego, CA, USA) using the GoldenGate Assay ${ }^{\mathrm{TM}}$ on the Illumina BeadLab [20-22] as part of a larger Mayo Clinic genetic association study. Successful genotyping was achieved for all 14 selected SNPs in the 798 cases and 843 controls. All but one of the 14 SNPs had MAF $\geq 0.05$ among the Mayo controls (Table 1). Concordance between 100 duplicate samples was $>99.99 \%$ for all assays.

\section{SEARCH replication study population}

Studies of Epidemiology and Risk Factors in Cancer Heredity (SEARCH), an ongoing population-based study of cases with invasive breast cancer ascertained through the Eastern Cancer Registration and Information Centre in England [23], was used as a second, independent study to evaluate significant breast cancer findings in the Mayo Clinic study. All women diagnosed after 1990 in the East Anglia region (median age = 51 years, range $=25$ to 69 years) were eligible, with approximately $65 \%$ of eligible breast cancer cases enrolled. Unaf- fected female controls (median age $=65$, range $=45$ to 81 years) from the same geographic region were randomly selected from the European Prospective Investigation into Cancer and Nutrition -Norfolk component of the European Prospective Investigation into Cancer and Nutrition in East Anglia, with $41 \%$ participation. Over $98 \%$ of cases and controls were white Europeans. The SEARCH study has been used extensively to evaluate associations between breast cancer risk and SNPs in various genes [23] and as part of a genome-wide association study for breast cancer [16].

Evaluation of the Mayo Clinic findings for $D C N$ rs3138165 and LUM rs2268578, the SNPs with the most significant associations with risk in each gene, was performed in the SEARCH study. These SNPs were selected for their strength of associations (point estimates and number of cases with two copies of the minor allele) with breast cancer risk to genotype in the SEARCH study comprising 4,470 cases and 4,560 controls with a $5^{\prime}$ nuclease assay $\left(\operatorname{Taqman}^{\circledR}\right.$ ) using the $\mathrm{ABI}$ PRISM 7900 HT Sequence Detection System according to manufacturer's instructions (Applied Biosystems, Foster City, CA, USA). Primers and probes were supplied directly by Applied Biosystems [24] as Assays-by-Design ${ }^{\mathrm{TM}}$. Successful genotyping was achieved for $98.6 \%$ of DNA samples.

\section{Statistical analysis}

Genotypes from the Mayo Clinic cases and controls were used to estimate allele frequencies. Among control subjects only, the genotypes were compared with those expected

\section{Table 1}

\begin{tabular}{|c|c|c|c|c|c|}
\hline Gene & Location & $\mathrm{rsID}$ & Polymorphic region & Amino acid change & MAF (controls) \\
\hline \multirow[t]{8}{*}{$D C N$} & $12 q 21.33$ & rs7441 & Ex8 G/A 3' UTR & & 0.06 \\
\hline & & rs3138268 & Ex7 G/A & Met268Thr & 0 \\
\hline & & rs516115 & IVS3 A/G & & 0.26 \\
\hline & & rs3138165a & IVS1 G/A 5' UTR & & 0.06 \\
\hline & & rs2070985a & IVS1 G/C 5' UTR & & 0.06 \\
\hline & & rs741212 & IVS1 A/G 5' UTR & & 0.12 \\
\hline & & $\mathrm{rs} 13312816^{a}$ & IVS1 A/T & & 0.06 \\
\hline & & rs10492230 & G/A 5' upstream & & 0.16 \\
\hline \multirow[t]{6}{*}{ LUM } & $12 q 21.3-q 22$ & rs1920790 & A/C 3' downstream & & 0.12 \\
\hline & & rs17714469 & G/A 3' downstream & & 0.10 \\
\hline & & rs10745553 & IVS2 G/C & & 0.15 \\
\hline & & rs2268578 & IVS2 G/A & & 0.11 \\
\hline & & rs10859110 & IVS1 G/A & & 0.22 \\
\hline & & rs17018765 & A/G 5' upstream & & 0.06 \\
\hline
\end{tabular}

aLinkage disequilibrium $r^{2} \geq 0.98$ for all pairwise combinations of these SNPs. 
under Hardy-Weinberg equilibrium using a Pearson goodness-of-fit test; no departures were found.

Pairwise linkage disequilibrium between SNPs was estimated with $r^{2}$ values [25] using Haploview [26]. Individual SNP associations for breast cancer risk were assessed using unconditional logistic regression to estimate the odds ratios (ORs) and 95\% confidence intervals (Cls). Analyses compared women with one copy and two copies of the minor allele with women with no copies using a two-degrees-of-freedom (2 df) model. We then assessed the dose-response effect of the SNP using an ordinal (log-additive) model.

Haplotype analyses were performed to identify whether the association with breast cancer risk could be informed further by phased combinations of alleles within each gene. Such combinations of alleles on a single chromosome can provide information about the possible presence of nearby breast cancer risk alleles that were not genotyped. Haplotype frequencies for each gene were estimated using all SNPs within the gene, and associations between individual haplotypes and breast cancer risk were evaluated compared with all other haplotypes combined. Haplotype frequencies for each gene were estimated using all SNPs within the gene, and a global haplotype score test of no association between haplotypes and breast cancer risk was evaluated at the gene level by the method proposed by Schaid and colleagues [27]. When the global haplotype score test suggested significance at the gene level, individual haplotype-specific associations for risk of breast cancer were compared with all other haplotypes combined.

In the SEARCH study, age-adjusted single-SNP associations were conducted using unconditional logistic regression under one-copy/two-copy and ordinal genetic models as described above.

In secondary analyses in both the Mayo Clinic and SEARCH studies, we stratified the data to evaluate the risk of breast cancer attributable to LUM rs2268578 in cases with estrogen receptor (ER)-positive and ER-negative tumors compared with control subjects because of recent reports of differential lumican protein expression by tumor ER status $[10,28]$.

Analyses were implemented using Haplo.stats [29], the SAS software system (version 8, 1999; SAS Institute, Cary, NC, USA) and the S-Plus software system (version 7.05, 2005; Insightful Corp., Seattle, WA, USA). Given prior hypotheses that SNPs in the DCN and $L U M$ genes are associated with breast cancer risk, corrections for multiple testing were not performed. Two-tailed $P \leq 0.05$ was considered statistically significant.

\section{Results}

Eight tagSNPs in DCN representing 21 individual SNPs and six tagSNPs in LUM representing 15 individual SNPs were identified from the HapMap (Table 1 and Figure 1). Of eight tagSNPs genotyped in $D C N$, three were highly correlated (rs3138165, rs2070985 and rs13312816: pairwise $r^{2} \geq$ 0.98). This redundancy resulted from genotyping all putative functional SNPs in addition to the tagSNPs; only data from one $D C N$ tagSNP (rs3138165) are therefore shown in subsequent analyses. Further, another DCN tagSNP (rs3138268) had $M A F=0$ among control subjects and was excluded from further analyses.

The Mayo Clinic cases and controls were adequately matched on age and region of residence, but differed in distribution by menopausal status, postmenopausal hormone use, age at menarche and smoking (Table 2). Covariates were evaluated for confounding in statistical models, and there was no appreciable difference in risk estimates of association when these covariates were excluded. The results for risk models are therefore presented adjusted for age and region of residence.

\section{Breast cancer risk analyses}

In the individual SNP analyses, three SNPs in DCN and three SNPs in LUM were associated with breast cancer risk in the Mayo Clinic sample: results of the one-copy/two-copy genetic model and of the ordinal model are presented in Table 3. The ORs associated with each copy of the minor allele varied slightly for $D C N$ rs7441 (OR $=1.3,95 \% \mathrm{Cl}=1.0$ to $1.7 ; P_{\text {trend }}$ $=0.05), D C N$ rs516115 (OR $=1.2,95 \% \mathrm{Cl}=1.0$ to 1.4 ; $\left.P_{\text {trend }}=0.03\right)$ and $D C N$ rs3138165 (OR $=1.3,95 \% \mathrm{Cl}=1.0$ to $\left.1.8 ; P_{\text {trend }}=0.03\right)$. In LUM, the associations with each copy of the minor allele were similar for $L U M$ rs2268578 (OR $=1.4$, $95 \% \mathrm{Cl}=1.2$ to $1.8 ; P_{\text {trend }}=0.0003$ ), LUM rs 10859110 (OR $=1.3,95 \% \mathrm{Cl}=1.1$ to $\left.1.5 ; P_{\text {trend }}=0.001\right)$ and $L U M$ rs17018765 (OR $=1.3,95 \% \mathrm{Cl}=1.0$ to $\left.1.7 ; P_{\text {trend }}=0.04\right)$.

At the gene level, only $\operatorname{LUM}(P=0.01)$ showed evidence of a significant association across haplotypes for breast cancer risk (Table 4). Of nine haplotypes observed in LUM, one sixSNP haplotype (haplotype $2 \mathrm{a}$ ) - accounting for $71 \%$ of all estimated haplotypes - was associated with decreased breast cancer risk $(P=0.01)$, while two separate haplotypes with 6\% (haplotype $2 \mathrm{~h}$ ) and $7 \%$ (haplotype 2i) frequency were associated with increased risk $(P \leq 0.03)$.

The DCN rs3138165 and LUM rs2268578 SNPs were genotyped in the SEARCH study. The association of $D C N$ rs3138165 in the Mayo Clinic sample was not confirmed in the SEARCH study, whereas LUM rs2268578 was positively associated with breast cancer risk but the ORs attenuated and did not reach statistical significance (Table 5). Compared with women with no copies of the minor allele in LUM rs2268578, women with two copies showed the greatest risk for breast cancer in both the Mayo Clinic sample $(\mathrm{OR}=2.2,95 \% \mathrm{Cl}=$ 


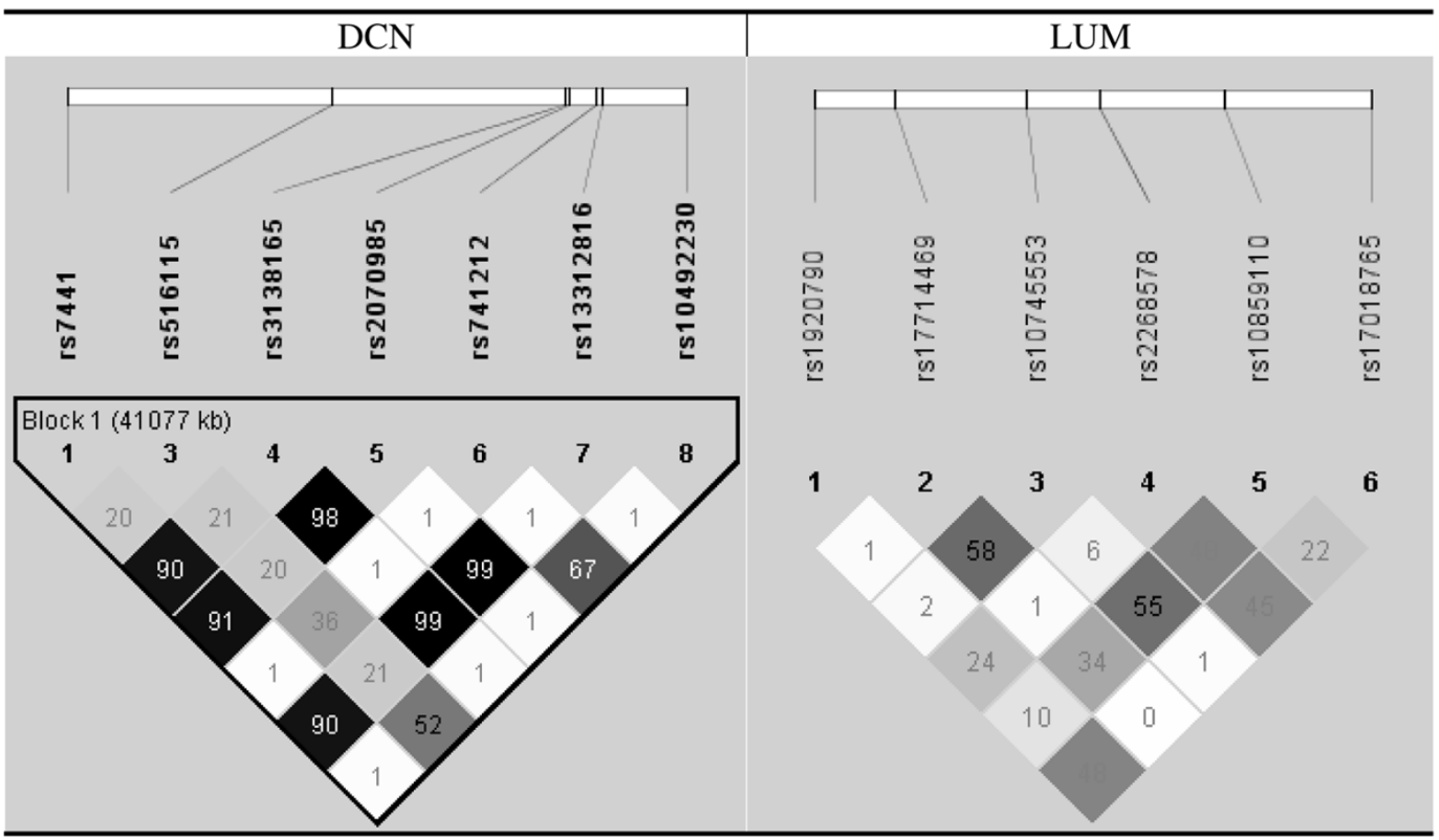

(a)

(b)

Linkage disequilibrium plots for polymorphisms in the $D C N$ and $L U M$ genes. Linkage disequilibrium (LD) plots for polymorphisms in the Mayo Clinic sample, 2001 to 2005, for (a) the decorin (DCN) gene and (b) the lumican (LUM) gene. Shaded regions indicate strength of LD between pairwise combinations of polymorphisms (white, $r^{2}=$ low LD; black, $r^{2}=$ near-perfect LD). Numbers in squares indicate estimates of the pairwise $r^{2}$. $D C N$ SNP rs3138268 had minor allele frequency $=0$ (absent in figure), and DCN SNPs rs3138165, rs2070985 and rs13312816 had pairwise $r^{2}$ $\geq 0.98$ : only rs3138165 was included in the statistical analyses.

1.1 to $\left.4.3 ; P_{2 \mathrm{df}}=0.002\right)$ and the SEARCH study sample (OR $=1.4,95 \% \mathrm{Cl}=1.0$ to $\left.2.1 ; P_{2 \mathrm{df}}=0.13\right)$. When the data from the two studies were pooled in age-adjusted and studyadjusted models, LUM rs2268578 was associated with increased risk among heterozygotes $(\mathrm{OR}=1.1,95 \% \mathrm{Cl}=1.0$ to 1.2 ) and homozygotes ( $\mathrm{OR}=1.6,95 \% \mathrm{Cl}=1.2$ to $2.3 ; P_{2}$ $\mathrm{df}=0.005$ ) (Table 5). The corresponding per-minor allele risk was $1.1\left(95 \% \mathrm{Cl}=1.0\right.$ to $\left.1.2 ; P_{\text {trend }}=0.004\right)$. These data suggest that LUM rs2268578 or a variant in strong linkage disequilibrium with rs2268578 may be a risk factor for breast cancer.

\section{Estrogen receptor subgroup analyses}

Women with two copies compared with no copies of the minor allele in LUM rs2268578 were at higher risk, compared with control individuals, of ER-positive breast cancer in both the Mayo Clinic study $\left(\mathrm{OR}=2.5,95 \% \mathrm{Cl}=1.2\right.$ to $5.3 ; P_{2 \mathrm{df}}=$ $0.001)$ and the SEARCH study (OR $=1.6,95 \% \mathrm{Cl}=1.0$ to $2.5 ; P_{2 \mathrm{df}}=0.10$ ) (Table 6). The per-minor allele risks were 1.5 $\left(95 \% \mathrm{Cl}=1.2\right.$ to $\left.1.9 ; P_{\text {trend }}=0.0003\right)$ in the Mayo Clinic sample and $1.1\left(95 \% \mathrm{Cl}=0.9\right.$ to $\left.1.2 ; P_{\text {trend }}=0.29\right)$ in the SEARCH sample. In pooled age-adjusted and study-adjusted analyses, LUM rs2268578 was associated with ER-positive tumors among heterozygotes $(\mathrm{OR}=1.1,95 \% \mathrm{Cl}=0.9$ to 1.2$)$ and homozygotes $\left(\mathrm{OR}=1.9,95 \% \mathrm{Cl}=1.3\right.$ to $2.8 ; P_{2} \mathrm{df}=$ $0.001)$. The corresponding per-minor allele risk was $1.1(95 \%$ $\mathrm{Cl}=1.0$ to $1.3 ; P_{\text {trend }}=0.01$ ).

The number of ER-negative cases was small in both samples and associations with breast cancer were not evident (Table 6 ). These data may suggest that the associations observed from the main effects models in both studies (Table 5) are due to the findings from ER-positive tumors. Almost one-half of SEARCH study tumors and one-quarter of Mayo Clinic tumors, however, could not be classified - precluding a definitive interpretation of the results, particularly for ER-negative breast cancer.

\section{Discussion}

We found a positive association between LUM rs2268578 and breast cancer risk in two large independent case-control studies, although the association in the SEARCH sample was attenuated and did not reach statistical significance. Two copies of the minor allele in LUM rs2268578 were associated 
Breast Cancer Research Vol 10 No 6 Kelemen et al.

Table 2

Demographic, personal and lifestyle characteristics among 1,641 Caucasian breast cancer cases and controls, Mayo Clinic 2001 to 2005

\begin{tabular}{|c|c|c|c|c|c|}
\hline \multirow[b]{2}{*}{ Characteristic } & \multirow[b]{2}{*}{ Level } & \multicolumn{2}{|c|}{ Cases $(n=798)$} & \multicolumn{2}{|c|}{ Controls $(n=843)$} \\
\hline & & $n$ & $\% a$ & $n$ & $\%$ \\
\hline \multirow[t]{5}{*}{ Age (years) } & 20 to 39 & 56 & 7 & 48 & 6 \\
\hline & 40 to 49 & 192 & 24 & 166 & 20 \\
\hline & 50 to 59 & 224 & 28 & 274 & 32 \\
\hline & 60 to 69 & 195 & 24 & 207 & 25 \\
\hline & $70+$ & 131 & 16 & 148 & 18 \\
\hline \multirow[t]{5}{*}{ State of residence } & Minnesota & 502 & 63 & 552 & 66 \\
\hline & Wisconsin & 69 & 9 & 78 & 9 \\
\hline & lowa & 128 & 16 & 147 & 17 \\
\hline & North Dakota/South Dakota & 52 & 6 & 41 & 5 \\
\hline & Illinois & 47 & 6 & 25 & 3 \\
\hline Body mass index $\left(\mathrm{kg} / \mathrm{m}^{2}\right)$ & Mean (standard deviation) & 28 & 8 & 27 & 8 \\
\hline Family history ${ }^{b}$ & Yes & 366 & 47 & 345 & 43 \\
\hline Postmenopausal status & Yes & 480 & 64 & 579 & 72 \\
\hline \multirow[t]{4}{*}{ Age at menarche (years) } & $<12$ & 132 & 18 & 122 & 16 \\
\hline & 12 & 224 & 31 & 184 & 24 \\
\hline & 13 & 218 & 30 & 238 & 32 \\
\hline & $\geq 14$ & 154 & 21 & 209 & 28 \\
\hline \multirow[t]{3}{*}{ Oral contraceptive use } & 0 months & 266 & 35 & 243 & 31 \\
\hline & 1 to 48 months & 185 & 24 & 189 & 24 \\
\hline & $48+$ months & 310 & 41 & 345 & 44 \\
\hline \multirow[t]{3}{*}{ Postmenopausal hormone use } & 0 months & 430 & 58 & 366 & 49 \\
\hline & 1 to 60 months & 131 & 18 & 160 & 22 \\
\hline & $60+$ months & 184 & 25 & 216 & 29 \\
\hline \multirow[t]{3}{*}{ Age at first birth (years) } & Nulliparous & 97 & 13 & 128 & 16 \\
\hline & $\leq 20$ years & 173 & 22 & 158 & 20 \\
\hline & $>20$ years & 501 & 65 & 514 & 64 \\
\hline \multirow[t]{3}{*}{ Smoking (pack years) } & None & 467 & 63 & 500 & 66 \\
\hline & $\leq 4$ years & 46 & 6 & 67 & 9 \\
\hline & $>4$ years & 231 & 31 & 192 & 25 \\
\hline \multirow[t]{4}{*}{ Alcohol consumption } & Never & 92 & 12 & 94 & 12 \\
\hline & Monthly & 332 & 43 & 327 & 41 \\
\hline & Weekly & 259 & 34 & 299 & 37 \\
\hline & Daily & 83 & 11 & 79 & 10 \\
\hline
\end{tabular}

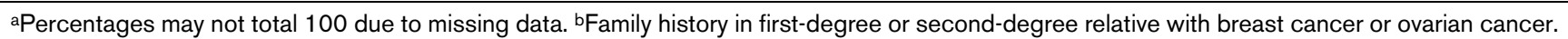


Odds ratios (OR) and $95 \%$ confidence intervals $(\mathrm{Cl})^{\mathrm{a}}$ between polymorphisms in the decorin (DCN) and lumican (LUM) genes and breast cancer risk among 1,641 Caucasian subjectsb, Mayo Clinic 2001 to 2005

\begin{tabular}{|c|c|c|c|c|c|c|c|c|c|c|c|}
\hline \multirow[t]{2}{*}{$\begin{array}{l}\text { Polymorphism/ } \\
\text { rsID }\end{array}$} & \multirow[t]{2}{*}{ MAF } & \multicolumn{2}{|c|}{$\begin{array}{l}\text { Homozygotes common allele } \\
\quad(\text { referent } \mathrm{OR}=1)\end{array}$} & \multicolumn{3}{|c|}{ Heterozygotes $^{c}$} & \multicolumn{3}{|c|}{ Homozygotes rare allelec } & \multirow{2}{*}{$\begin{array}{l}\text { Per allele } \\
\text { OR } \\
(95 \% \mathrm{Cl})\end{array}$} & \multirow[t]{2}{*}{$P$ trend } \\
\hline & & Cases & Controls & Cases & Controls & $\begin{array}{l}\text { OR } \\
(95 \% \mathrm{Cl})\end{array}$ & Cases & Controls & $\begin{array}{l}\text { OR } \\
(95 \% \mathrm{Cl})\end{array}$ & & \\
\hline \multicolumn{12}{|l|}{$D C N$} \\
\hline rs7441 & 0.06 & 675 & 744 & 119 & 95 & $\begin{array}{l}1.3 \\
(1.0 \text { to } 1.8)\end{array}$ & 4 & 4 & $\begin{array}{l}1.2 \\
(0.3 \text { to } 4.7)\end{array}$ & $\begin{array}{l}1.3 \\
(1.0 \text { to } 1.7)\end{array}$ & 0.05 \\
\hline rs516115 & 0.26 & 397 & 470 & 336 & 316 & $\begin{array}{l}1.2 \\
(1.0 \text { to } 1.5)\end{array}$ & 65 & 57 & $\begin{array}{l}1.3 \\
(0.9 \text { to } 2.0)\end{array}$ & $\begin{array}{l}1.2 \\
(1.0 \text { to } 1.4)\end{array}$ & 0.03 \\
\hline rs3138165 & 0.06 & 668 & 741 & 123 & 98 & $\begin{array}{l}1.4 \\
(1.0 \text { to } 1.8)\end{array}$ & 6 & 4 & $\begin{array}{l}1.8 \\
(0.5 \text { to } 6.3)\end{array}$ & $\begin{array}{l}1.3 \\
(1.0 \text { to } 1.8)\end{array}$ & 0.03 \\
\hline rs741212 & 0.12 & 616 & 662 & 167 & 167 & $\begin{array}{l}1.1 \\
(0.8 \text { to } 1.4)\end{array}$ & 15 & 14 & $\begin{array}{l}1.2 \\
(0.6 \text { to } 2.5)\end{array}$ & $\begin{array}{l}1.1 \\
(0.9 \text { to } 1.3)\end{array}$ & 0.51 \\
\hline rs10492230 & 0.16 & 557 & 589 & 216 & 231 & $\begin{array}{l}1.0 \\
(0.8 \text { to } 1.2)\end{array}$ & 25 & 23 & $\begin{array}{l}1.2 \\
(0.7 \text { to } 2.1)\end{array}$ & $\begin{array}{l}1.0 \\
(0.8 \text { to } 1.2)\end{array}$ & 0.88 \\
\hline \multicolumn{12}{|l|}{ LUM } \\
\hline rs1920790 & 0.12 & 594 & 653 & 188 & 180 & $\begin{array}{l}1.1 \\
(0.9 \text { to } 1.4)\end{array}$ & 16 & 10 & $\begin{array}{l}1.8 \\
(0.8 \text { to } 3.9)\end{array}$ & $\begin{array}{l}1.2 \\
(0.9 \text { to } 1.4)\end{array}$ & 0.13 \\
\hline rs17714469 & 0.10 & 647 & 683 & 141 & 152 & $\begin{array}{l}1.0 \\
(0.7 \text { to } 1.2)\end{array}$ & 10 & 8 & $\begin{array}{l}1.3 \\
(0.5 \text { to } 3.3)\end{array}$ & $\begin{array}{l}1.0 \\
(0.8 \text { to } 1.3)\end{array}$ & 1.0 \\
\hline rs10745553 & 0.15 & 559 & 613 & 214 & 212 & $\begin{array}{l}1.1 \\
(0.9 \text { to } 1.4)\end{array}$ & 24 & 17 & $\begin{array}{l}1.6 \\
(0.8 \text { to } 3.0)\end{array}$ & $\begin{array}{l}1.1 \\
(0.9 \text { to } 1.4)\end{array}$ & 0.14 \\
\hline rs2268578 & 0.11 & 567 & 661 & 207 & 167 & $\begin{array}{l}1.4 \\
(1.1 \text { to } 1.8)\end{array}$ & 23 & 13 & $\begin{array}{l}2.2(1.1 \text { to } \\
4.3)^{d}\end{array}$ & $\begin{array}{l}1.4 \\
(1.2 \text { to } 1.8)\end{array}$ & 0.0003 \\
\hline rs10859110 & 0.22 & 418 & 517 & 331 & 283 & $\begin{array}{l}1.4 \\
(1.2 \text { to } 1.7)\end{array}$ & 49 & 43 & $\begin{array}{l}1.4(0.9 \text { to } \\
2.2)^{\mathrm{d}}\end{array}$ & $\begin{array}{l}1.3 \\
(1.1 \text { to } 1.5)\end{array}$ & 0.001 \\
\hline rs17018765 & 0.06 & 673 & 744 & 121 & 95 & $\begin{array}{l}1.4 \\
(1.0 \text { to } 1.8)\end{array}$ & 4 & 4 & $\begin{array}{l}1.2 \\
(0.3 \text { to } 4.7)\end{array}$ & $\begin{array}{l}1.3 \\
(1.0 \text { to } 1.7)\end{array}$ & 0.04 \\
\hline
\end{tabular}

MAF, minor allele frequency. aAdjusted for age and region of residence (Minnesota, lowa, Wisconsin, Illinois, North Dakota and South Dakota). b798 cases and 843 controls. 'Referent $(\mathrm{OR}=1)$ is homozygous common allele group. dTwo-degrees-of-freedom test, $P=0.002$.

with an average $60 \%$ increased risk of breast cancer compared with women with no copies, and the data suggest increased risk for ER-positive tumors. DCN rs3138165 was positively associated with breast cancer risk in the Mayo Clinic sample but the finding was not confirmed in the SEARCH sample. Haplotypes from each gene were also associated with breast cancer risk in the Mayo Clinic sample.

The weaker association of LUM rs2268578 with breast cancer risk in the SEARCH sample may be due to a lack of causal association of this SNP with breast cancer, or the results may be a more valid estimate of effect. It is not uncommon for replicated findings to report ORs for the variant homozygote that are weaker compared with the initial study's findings, a phenomenon known as winner's curse [30]. Furthermore, a small sample size can frequently result in insufficient power to detect minor contributions of one or more alleles [30] - as we observed with the results from the SEARCH sample.

In post hoc evaluation we also compared our results for LUM rs2268578 with those from the Cancer Genetic Markers of Susceptibility (CGEMS) genome-wide association study of breast cancer risk among 1,145 postmenopausal breast cancer cases and 1,142 controls of European ancestry from the Nurses' Health Study [31,32]. When restricted to postmenopausal women, the associations with breast cancer risk were weaker but remained positive in the Mayo Clinic and SEARCH samples; however, in the CGEMS data, women with one copy $(\mathrm{OR}=1.1)$ or two copies (OR $\left.=0.9, P_{2 \mathrm{df}}=0.52\right)$, compared with no copies, of the minor allele were not at risk of breast cancer despite similar MAF $=0.12$ among controls. The CGEMS data did not report ER-positive or ER-negative 
Table 4

Gene-levela analysis of the decorin ( $D C N)$ and lumican (LUM) genes with breast cancer risk among 1,641 Caucasian subjects ${ }^{\mathrm{b}}$, Mayo Clinic 2001 to 2005

\begin{tabular}{|c|c|c|c|c|}
\hline Gene/haplotype & $\begin{array}{l}\text { Global haplotype score test } P \\
\text { value }\end{array}$ & $\begin{array}{l}\text { Estimated haplotype } \\
\text { frequency }\end{array}$ & $\begin{array}{l}\text { Individual haplotype score } \\
\text { test }^{c}\end{array}$ & Individual haplotype $P$ value \\
\hline$D C N e$ & 0.18 & & & \\
\hline 1a: AAAAC & & 0.73 & -2.19 & 0.03 \\
\hline 1b: AGAAT & & 0.05 & -0.65 & 0.52 \\
\hline 1c: GGAAC & & 0.001 & 0.38 & 0.70 \\
\hline 1d: AGAGT & & 0.12 & 0.59 & 0.55 \\
\hline 1e: AGGAC & & 0.004 & 0.82 & 0.41 \\
\hline 1f: AGAAC & & 0.03 & 1.82 & 0.07 \\
\hline 1g: GGGAC & & 0.07 & 1.92 & 0.05 \\
\hline LUM ${ }^{\ddagger}$ & 0.01 & & & \\
\hline 2a: AGGGGA & & 0.71 & -2.44 & 0.01 \\
\hline 2b: CGGGGA & & 0.05 & -0.74 & 0.46 \\
\hline 2c: CGGGAA & & 0.004 & -0.04 & 0.97 \\
\hline 2d: AACGAA & & 0.10 & 0.42 & 0.67 \\
\hline 2e: AGGGAA & & 0.003 & 0.89 & 0.37 \\
\hline 2f: CGGAAA & & 0.01 & 1.08 & 0.28 \\
\hline 2g: AGGAAA & & 0.003 & 1.38 & 0.17 \\
\hline 2h: AGCAAA & & 0.06 & 2.18 & 0.03 \\
\hline 2i: CGGAAG & & 0.07 & 2.29 & 0.02 \\
\hline
\end{tabular}

aAdjusted for age and region of residence (Minnesota, lowa, Wisconsin, Illinois, North Dakota and South Dakota). b798 cases and 843 controls. cScore statistics comparing haplotype of interest with all other haplotypes combined. Negative values imply decreased risk of breast cancer, whereas positive values imply increased risk. $d P$ value comparing haplotype of interest with all other haplotypes combined. eHaplotype-forming SNPs in DCN are rs7441 (A/G), rs516115 (A/G), rs3138165 (A/G), rs741212 (A/G), rs10492230 (A/G). fHaplotype-forming SNPs in LUM are rs1920790 (A/C), rs17714469 (G/A), rs10745553(G/C), rs2268578 (G/A), rs10859110 (G/A), rs17018765 (A/G).

results. At MAF $=0.12$, if the true OR for homozygotes is in the range 1.1 to 1.5 , then a much larger study than SEARCH or CGEMS would be needed to have sufficient power to replicate the association at either the conventional $(P \leq 0.05)$ or the genome-wide $\left(P \leq 10^{-7}\right)$ level of significance. It should be noted that, even in the combined Mayo Clinic and SEARCH samples, there were only 108 cases and 75 controls homozygous for the minor allele. Comparable information from CGEMS is not available. It remains possible that the distribution of other exposures - for example, $60 \%$ of Mayo Clinic cases did not use postmenopausal hormones versus $<30 \%$ in the Nurses' Health Study [33] - may also explain the differences in genetic associations with CGEMS.

The hypothesis that genetic variation in $L U M$ is associated with breast cancer is based on a recent series of reports by Watson and colleagues of altered regulation of LUM in human breast tumors [10,11]. Using in situ hybridization and western blot techniques, LUM mRNA levels were significantly higher
$(P<0.0001)$ in stroma associated with breast carcinoma compared with stroma associated with adjacent normal tissue in the same woman [11]. In the present study, the observed risk associated with breast cancer from the $L U M$ intronic SNP rs2268578 or from a SNP in strong linkage disequilibrium with rs2268578 may be consistent with increased protein expression of lumican in the study by Leygue and colleagues [11], if it represents a negative host response contributing to early tumor development through increased proteolysis or altered lumican deposition that precedes disorganized collagenous stroma [11]. Elucidation of the functional impact of the LUM $\mathrm{SNP}(\mathrm{s})$ is needed in order to provide insight into the effects on risk.

Associations with breast cancer risk for the DCN and LUM genes were observed with haplotype analyses in the Mayo Clinic sample. Of note, the three haplotypes in LUM that were associated with breast cancer risk had in common the $G$ allele at position 2 ( $r$ 17714469) and a graduated change in the 
Odds ratios (OR) and $95 \%$ confidence intervals $(\mathrm{CI})$ a between polymorphisms in the decorin $(D C N)$ and lumican (LUM) genes and breast cancer risk among 1,641 Caucasian subjects (Mayo Clinic 2001 to 2005) and 9,030 Caucasian subjects (SEARCH study 1990 2005)

\begin{tabular}{|c|c|c|c|c|c|c|c|c|c|c|}
\hline \multirow{3}{*}{ Model } & \multicolumn{5}{|c|}{$D C N$ rs3138165 } & \multicolumn{5}{|c|}{ LUM rs2268578 } \\
\hline & \multicolumn{2}{|c|}{$\begin{array}{l}\text { Mayo Clinic sample } \\
(\mathrm{MAF}=0.06)\end{array}$} & \multicolumn{2}{|c|}{$\begin{array}{l}\text { SEARCH sample } \\
(\mathrm{MAF}=0.07)\end{array}$} & \multirow{2}{*}{$\begin{array}{l}\text { Pooled } \\
\text { Mayo } \\
\text { Clinic + } \\
\text { SEARCH } \\
\text { sample } \\
\\
\text { OR } \\
(95 \% \mathrm{Cl})\end{array}$} & \multicolumn{2}{|c|}{$\begin{array}{l}\text { Mayo Clinic sample } \\
(\mathrm{MAF}=0.11)\end{array}$} & \multicolumn{2}{|c|}{$\begin{array}{l}\text { SEARCH sample } \\
(\mathrm{MAF}=0.12)\end{array}$} & \multirow{2}{*}{$\begin{array}{l}\begin{array}{l}\text { Pooled } \\
\text { Mayo } \\
\text { Clinic + } \\
\text { SEARCH } \\
\text { sample }\end{array} \\
\\
\text { OR } \\
(95 \% \mathrm{Cl})\end{array}$} \\
\hline & $\begin{array}{l}\text { Cases/ } \\
\text { controls }\end{array}$ & $\begin{array}{l}\text { OR } \\
(95 \% \mathrm{Cl})\end{array}$ & $\begin{array}{l}\text { Cases/ } \\
\text { controls }\end{array}$ & $\begin{array}{l}\text { OR } \\
(95 \% \mathrm{Cl})\end{array}$ & & $\begin{array}{l}\text { Cases/ } \\
\text { controls }\end{array}$ & $\begin{array}{l}\text { OR } \\
(95 \% \mathrm{Cl})\end{array}$ & $\begin{array}{l}\text { Cases/ } \\
\text { controls }\end{array}$ & $\begin{array}{l}\text { OR } \\
(95 \% \mathrm{Cl})\end{array}$ & \\
\hline \multicolumn{11}{|l|}{ General } \\
\hline 0 copy & $668 / 741$ & $\begin{array}{l}1.0 \\
\text { (referent) }\end{array}$ & $\begin{array}{l}3,801 / \\
3,965\end{array}$ & $\begin{array}{l}1.0 \\
\text { (referent) }\end{array}$ & $\begin{array}{l}1.0 \\
\text { (referent) }\end{array}$ & $567 / 661$ & $\begin{array}{l}1.0 \\
\text { (referent) }\end{array}$ & $\begin{array}{l}3,306 / \\
3,506\end{array}$ & $\begin{array}{l}1.0 \\
\text { (referent) }\end{array}$ & $\begin{array}{l}1.0 \\
\text { (referent) }\end{array}$ \\
\hline 1 copy & $123 / 98$ & $\begin{array}{l}1.4 \\
(1.0 \text { to } \\
1.8)\end{array}$ & $547 / 558$ & $\begin{array}{l}1.0 \\
(0.9 \text { to } \\
1.2)\end{array}$ & $\begin{array}{l}1.1 \\
(0.9 \text { to } \\
1.2)\end{array}$ & $207 / 167$ & $\begin{array}{l}1.4 \\
(1.1 \text { to } \\
1.8)\end{array}$ & $972 / 980$ & $\begin{array}{l}1.1 \\
(0.9 \text { to } \\
1.2)\end{array}$ & $\begin{array}{l}1.1 \\
(1.0 \text { to } \\
1.2)\end{array}$ \\
\hline $\begin{array}{l}2 \\
\text { copies }\end{array}$ & $6 / 4$ & $\begin{array}{l}1.8 \\
(0.5 \text { to } \\
6.3)\end{array}$ & $19 / 20$ & $\begin{array}{l}0.8 \\
(0.4 \text { to } \\
1.7)\end{array}$ & $\begin{array}{l}1.1 \\
(0.6 \text { to } \\
2.1)\end{array}$ & $23 / 13$ & $\begin{array}{l}2.2 \\
(1.1 \text { to } \\
4.3)\end{array}$ & $85 / 62$ & $\begin{array}{l}1.4 \\
(1.0 \text { to } \\
2.1)\end{array}$ & $\begin{array}{l}1.6 \\
(1.2 \text { to } \\
2.3)\end{array}$ \\
\hline$P$ value ${ }^{c}$ & & 0.08 & & 0.87 & 0.61 & & 0.002 & & 0.13 & 0.005 \\
\hline Ordinal & & $\begin{array}{l}1.3 \\
(1.0 \text { to } \\
1.8)\end{array}$ & & $\begin{array}{l}1.0 \\
(0.9 \text { to } \\
1.1)\end{array}$ & $\begin{array}{l}1.1 \\
(0.9 \text { to } \\
1.2)\end{array}$ & & $\begin{array}{l}1.4 \\
(1.2 \text { to } \\
1.8)\end{array}$ & & $\begin{array}{l}1.1 \\
(1.0 \text { to } \\
1.2)\end{array}$ & $\begin{array}{l}1.1 \\
(1.0 \text { to } \\
1.2)\end{array}$ \\
\hline$P$ trend & & 0.03 & & 0.96 & 0.32 & & 0.0003 & & 0.10 & 0.004 \\
\hline
\end{tabular}

MAF, minor allele frequency. ${ }^{a}$ Mayo Clinic sample adjusted for age and region of residence (Minnesota, lowa, Wisconsin, Illinois, North Dakota and South Dakota); SEARCH sample adjusted for age; pooled Mayo Clinic + SEARCH sample adjusted for age and study. ${ }^{b 798} \mathrm{cases}$ and 843 controls (Mayo Clinic sample), and 4,470 cases and 4,560 controls (SEARCH sample). cTwo-degrees-of-freedom test.

combination of alleles in the last three positions ( $r$ 2268578, rs10859110 and rs17018765) from GGA (haplotype 2a), associated with decreased risk, to AAA (haplotype $2 \mathrm{~h}$ ) and AAG (haplotype $2 \mathrm{~g}$ ), each associated with increased risk. It is possible that the association between breast cancer risk and these inferred haplotypes may be attributable to LUM rs2268578 or a SNP in strong linkage disequilibrium with rs2268578 because this single SNP was also associated with risk in both the Mayo Clinic and SEARCH samples. Further association testing in this chromosomal region - based on genotypes from a denser marker set - is required, however, in order to fully understand the nature of the relationship.

The increased risk of breast cancer from LUM rs2268578 may be due to the positive association with ER-positive breast tumors in both the Mayo Clinic and SEARCH samples, although the analyses were underpowered and were not based on a priori hypotheses. The association between lumican expression and ER-positive breast tumors is supported by the findings from two studies $[10,28]$. Troup and colleagues [10] found that a greater number of ER-positive tumors ( $n=$ 99) compared with ER-negative tumors $(n=6)$ had lumican protein expression $\geq 25$ th percentile among 140 women with breast cancer $(P=0.002)$. Mackay and colleagues [28] evaluated gene microarray expression profiles in biopsies obtained from 34 women with primary ER-positive breast cancer before and after a 2-week intervention of aromatase inhibitor treatment. Among the 2,418 genes with the greatest variability in expression, the LUM gene was the most highly upregulated by a factor, on average, of 2.9 -fold following aromatase inhibitor treatment, and the $D C N$ gene was upregulated by a factor of 2.3. Collectively, these data suggest a potential mechanistic link between LUM expression and ERpositive tumors, which requires further investigation.

The strengths of the present study include the incorporation of a second, independent large sample of cases and controls to confirm initial findings. Our study populations were enrolled from defined regions, were of Caucasian ancestry and were less probably influenced by population stratification [34]. This does not necessarily, however, allow generalization of the observed association with breast cancer to other ethnic/racial populations [35]. One limitation is that the classification of tumors by ER status was not centrally reviewed and a large 
Odds ratios (OR) and 95\% confidence intervals (CI)a between LUM SNP rs2268578 and breast cancer risk, stratified by tumor estrogen receptor status among 1,641 Caucasian subjects (Mayo Clinic 2001 to 2005) and 9,030 Caucasian subjects (SEARCH study 1990 to 2005)

\begin{tabular}{|c|c|c|c|c|c|c|c|c|c|c|}
\hline \multirow{3}{*}{ Model } & \multicolumn{5}{|c|}{ Estrogen receptor-positive } & \multicolumn{5}{|c|}{ Estrogen receptor-negative } \\
\hline & \multicolumn{2}{|c|}{ Mayo Clinic sample } & \multicolumn{2}{|c|}{ SEARCH sample } & \multirow{2}{*}{$\begin{array}{c}\begin{array}{c}\text { Pooled } \\
\text { Mayo } \\
\text { Clinic + } \\
\text { SEARCH } \\
\text { sample }\end{array} \\
\\
\text { OR } \\
(95 \% \mathrm{Cl})\end{array}$} & \multicolumn{2}{|c|}{ Mayo Clinic sample } & \multicolumn{2}{|c|}{ SEARCH sample } & \multirow{2}{*}{$\begin{array}{c}\begin{array}{c}\text { Pooled } \\
\text { Mayo } \\
\text { Clinic + } \\
\text { SEARCH } \\
\text { sample }\end{array} \\
\\
\text { OR } \\
(95 \% \mathrm{Cl})\end{array}$} \\
\hline & $\begin{array}{l}\text { Cases/ } \\
\text { controls }\end{array}$ & $\begin{array}{l}\text { OR } \\
(95 \% \mathrm{Cl})\end{array}$ & $\begin{array}{l}\text { Cases/ } \\
\text { controls }\end{array}$ & $\begin{array}{l}\text { OR } \\
\text { (95\% Cl) }\end{array}$ & & $\begin{array}{l}\text { Cases/ } \\
\text { controls }\end{array}$ & $\begin{array}{l}\text { OR } \\
(95 \% \mathrm{Cl})\end{array}$ & $\begin{array}{l}\text { Cases/ } \\
\text { controls }\end{array}$ & $\begin{array}{l}\text { OR } \\
(95 \% \mathrm{Cl})\end{array}$ & \\
\hline \multicolumn{11}{|l|}{ General } \\
\hline 0 copy & $340 / 661$ & $\begin{array}{l}1.0 \\
\text { (referent) }\end{array}$ & $\begin{array}{l}1,506 / \\
3,506\end{array}$ & $\begin{array}{l}1.0 \\
\text { (referent) }\end{array}$ & $\begin{array}{l}1.0 \\
\text { (referent) }\end{array}$ & $86 / 661$ & $\begin{array}{l}1.0 \\
\text { (referent) }\end{array}$ & $344 / 3,506$ & $\begin{array}{l}1.0 \\
\text { (referent) }\end{array}$ & $\begin{array}{l}1.0 \\
\text { (referent) }\end{array}$ \\
\hline 1 copy & $125 / 167$ & $\begin{array}{l}1.5 \\
(1.1 \text { to } \\
1.9)\end{array}$ & $431 / 980$ & $\begin{array}{l}1.0 \\
(0.9 \text { to } \\
1.1)\end{array}$ & $\begin{array}{l}1.1 \\
(0.9 \text { to } \\
1.2)\end{array}$ & $20 / 167$ & $\begin{array}{l}0.9 \\
(0.5 \text { to } \\
1.5)\end{array}$ & $107 / 980$ & $\begin{array}{l}1.0 \\
(0.8 \text { to } \\
1.4)\end{array}$ & $\begin{array}{l}1.0 \\
(0.8 \text { to } \\
1.3)\end{array}$ \\
\hline $\begin{array}{l}2 \\
\text { copies }\end{array}$ & $17 / 13$ & $\begin{array}{l}2.5 \\
(1.2 \text { to } \\
5.3)\end{array}$ & $47 / 62$ & $\begin{array}{l}1.6 \\
(1.0 \text { to } \\
2.5)\end{array}$ & $\begin{array}{l}1.9 \\
(1.3 \text { to } \\
2.8)\end{array}$ & $3 / 13$ & $\begin{array}{l}1.7 \\
(0.4 \text { to } \\
6.5)\end{array}$ & $5 / 62$ & $\begin{array}{l}0.8 \\
(0.3 \text { to } \\
2.0)\end{array}$ & $\begin{array}{l}1.0 \\
(0.5 \text { to } \\
2.2)\end{array}$ \\
\hline$P$ value ${ }^{c}$ & & 0.001 & & 0.10 & 0.001 & & 0.67 & & 0.79 & 0.98 \\
\hline Ordinal & & $\begin{array}{l}1.5 \\
(1.2 \text { to } \\
1.9)\end{array}$ & & $\begin{array}{l}1.1 \\
(0.9 \text { to } \\
1.2)\end{array}$ & $\begin{array}{l}1.1 \\
(1.0 \text { to } \\
1.3)\end{array}$ & & $\begin{array}{l}1.0 \\
(0.7 \text { to } \\
1.6)\end{array}$ & & $\begin{array}{l}1.0 \\
(0.8 \text { to } \\
1.3)\end{array}$ & $\begin{array}{l}1.0 \\
(0.8 \text { to } \\
1.2)\end{array}$ \\
\hline$P$ trend & & 0.0003 & & 0.29 & 0.01 & & 0.89 & & 0.93 & 0.86 \\
\hline
\end{tabular}

aMayo sample adjusted for age and region of residence (Minnesota, lowa, Wisconsin, Illinois, North Dakota and South Dakota); SEARCH sample adjusted for age; pooled Mayo + SEARCH sample adjusted for age and study. b798 cases and 843 controls (Mayo Clinic sample), and 4,470 cases and 4,560 controls (SEARCH sample). Numbers do not total due to missing tumor status: 1,985 (44\%) in SEARCH and 206 (26\%) in Mayo Clinic sample. 'Two-degrees-of-freedom test.

proportion of tumors could not be classified, hampering a strong conclusion of the association of the LUM SNP by ER status. Furthermore, it remains possible that the other variants in $D C N$ and $L U M$ that were not selected for genotyping in SEARCH may also influence breast cancer risk.

\section{Conclusion}

Although LUM rs2268578 was associated with breast cancer in the Mayo Clinic study, particularly ER-positive breast cancer, weaker and modest associations were observed in the SEARCH sample. Evaluation of this SNP in a larger study (such as the Breast Cancer Association Consortium) along with functional studies will be needed to adequately assess the importance of this SNP in breast cancer.

\section{Competing interests}

The authors declare that they have no competing interests.

\section{Authors' contributions}

LEK drafted the manuscript. LEK, FJC and CMV revised the manuscript for intellectual content. CMV conceived the study hypothesis and selected the genes. FJC, VSP, ELG, DNR, $\mathrm{XW}, \mathrm{JRC}$ and $\mathrm{CMV}$ designed the Mayo Clinic study and acquired data. ZSF, RAV, VSP and CGS performed the statistical analyses. FJC and CMV were responsible for funding for the Mayo Clinic Study. AMD, PDPP and DFE were responsible for study design and funding for, and SA for genotyping in, the SEARCH study. All authors contributed to data interpretation, and read and approved the final manuscript.

\section{Acknowledgements}

The present project was supported by grants from the National Institutes of Health (NCI P50 CA116201 and NCI R01 CA122340). NCI P50 CA116201 is a Breast Specialized Program Of Research Excellence grant that provided funding for statistical analyses, interpretation of the data and writing of the manuscript. NCI R01 CA122340 also provided funding for the genotyping, statistical analyses, interpretation of the data and writing of the manuscript. SEARCH is funded through a program grant from Cancer Research UK. PDPP is a Cancer Research UK Senior Clinical Research Fellow. The decision to submit the manuscript was independent of the funding source.

\section{References}

1. Barcellos-Hoff MH, Ravani SA: Irradiated mammary gland stroma promotes the expression of tumorigenic potential by unirradiated epithelial cells. Cancer Res 2000, 60:1254-1260.

2. Brown LF, Guidi AJ, Schnitt SJ, Water L Van De, Iruela-Arispe ML, Yeo TK, Tognazzi K, Dvorak HF: Vascular stroma formation in 
carcinoma in situ, invasive carcinoma, and metastatic carcinoma of the breast. Clin Cancer Res 1999, 5:1041-1056.

3. Peyrol S, Raccurt M, Gerard F, Gleyzal C, Grimaud JA, Sommer P: Lysyl oxidase gene expression in the stromal reaction to in situ and invasive ductal breast carcinoma. Am J Pathol 1997, 150:497-507.

4. Ronnov-Jessen L, Petersen OW, Bissell MJ: Cellular changes involved in conversion of normal to malignant breast: importance of the stromal reaction. Physiol Rev 1996, 76:69-125

5. Kinzler KW, Vogelstein B: Landscaping the cancer terrain. Science 1998, 280:1036-1037.

6. Hocking AM, Shinomura T, McQuillan DJ: Leucine-rich repeat glycoproteins of the extracellular matrix. Matrix Biol 1998, 17:1-19.

7. Danielson KG, Baribault $H$, Holmes DF, Graham H, Kadler KE, lozzo RV: Targeted disruption of decorin leads to abnormal collagen fibril morphology and skin fragility. J Cell Biol 1997, 136:729-743.

8. Chakravarti S, Magnuson T, Lass JH, Jepsen KJ, LaMantia C, Carroll $\mathrm{H}$ : Lumican regulates collagen fibril assembly: skin fragility and corneal opacity in the absence of lumican. J Cell Biol 1998, 141:1277-1286.

9. Reed CC, Waterhouse A, Kirby S, Kay P, Owens RT, McQuillan DJ, lozzo RV: Decorin prevents metastatic spreading of breast cancer. Oncogene 2005, 24:1104-1110.

10. Troup S, Njue C, Kliewer EV, Parisien M, Roskelley C, Chakravarti $\mathrm{S}$, Roughley PJ, Murphy LC, Watson PH: Reduced expression of the small leucine-rich proteoglycans, lumican, and decorin is associated with poor outcome in node-negative invasive breast cancer. Clin Cancer Res 2003, 9:207-214.

11. Leygue E, Snell L, Dotzlaw H, Troup S, Hiller-Hitchcock T, Murphy LC, Roughley PJ, Watson PH: Lumican and decorin are differentially expressed in human breast carcinoma. J Pathol 2000, 192:313-320.

12. Alowami S, Troup S, Al-Haddad S, Kirkpatrick I, Watson PH: Mammographic density is related to stroma and stromal proteoglycan expression. Breast Cancer Res 2003, 5:R129-R135.

13. Moinfar F, Man YG, Arnould L, Bratthauer GL, Ratschek M, Tavassoli FA: Concurrent and independent genetic alterations in the stromal and epithelial cells of mammary carcinoma: implications for tumorigenesis. Cancer Res 2000, 60:2562-2566.

14. Kurose K, Hoshaw-Woodard S, Adeyinka A, Lemeshow S, Watson $\mathrm{PH}$, Eng C: Genetic model of multi-step breast carcinogenesis involving the epithelium and stroma: clues to tumour-microenvironment interactions. Hum Mol Genet 2001, 10:1907-1913.

15. Kurose K, Gilley K, Matsumoto S, Watson PH, Zhou XP, Eng C: Frequent somatic mutations in PTEN and TP53 are mutually exclusive in the stroma of breast carcinomas. Nat Genet 2002, 32:355-357.

16. Easton DF, Pooley KA, Dunning AM, Pharoah PD, Thompson D, Ballinger DG, Struewing JP, Morrison J, Field H, Luben R, Wareham N, Ahmed S, Healey CS, Bowman R, SEARCH collaborators, Meyer KB, Haiman CA, Kolonel LK, Henderson BE, Le Marchand $L$ Brennan P, Sangrairang S, Gaborieau V, Odefrey F, Shen CY, Wu PE, Wang HC, Eccles D, Evans DG, Peto J, et al.: Genomewide association study identifies novel breast cancer susceptibility loci. Nature 2007, 447:1087-1093.

17. Cox A, Dunning AM, Garcia-Closas M, Balasubramanian S, Reed MW, Pooley KA, Scollen S, Baynes C, Ponder BA, Chanock S, Lissowska J, Brinton L, Peplonska B, Southey MC, Hopper JL, McCredie MR, Giles GG, Fletcher O, Johnson N, dos Santos Silva I, Gibson L, Bojesen SE, Nordestgaard BG, Axelsson CK, Torres D, Hamann U, Justenhoven C, Brauch H, Chang-Claude J, Kropp $\mathrm{S}$, et al: : A common coding variant in CASP8 is associated with breast cancer risk. Nat Genet 2007, 39:352-358.

18. The International HapMap Consortium: The International HapMap Project. Nature 2003, 426:789-796.

19. Carlson CS, Eberle MA, Rieder MJ, Yi Q, Kruglyak L, Nickerson DA: Selecting a maximally informative set of single-nucleotide polymorphisms for association analyses using linkage disequilibrium. Am J Hum Genet 2004, 74:106-120.

20. Steemers FJ, Gunderson KL: Illumina, Inc. Pharmacogenomics 2005, 6:777-782.

21. Oliphant A, Barker DL, Stuelpnagel JR, Chee MS: BeadArray technology: enabling an accurate, cost-effective approach to high-throughput genotyping. Biotechniques 2002:56-61.
22. Fan JB, Hu SX, Craumer WC, Barker DL: BeadArray-based solutions for enabling the promise of pharmacogenomics. Biotechniques 2005, 39:583-588.

23. Pharoah PD, Tyrer J, Dunning AM, Easton DF, Ponder BA: Association between common variation in 120 candidate genes and breast cancer risk. PLoS Genet 2007, 3:e42.

24. Applied Biosystems [http://www.appliedbiosystems.com/]

25. Devlin B, Risch N: A comparison of linkage disequilibrium measures for fine-scale mapping. Genomics 1995, 29:311-322.

26. Barrett JC, Fry B, Maller J, Daly MJ: Haploview: analysis and visualization of LD and haplotype maps. Bioinformatics (Oxford, England) 2005, 21:263-265.

27. Schaid DJ, Rowland CM, Tines DE, Jacobson RM, Poland GA: Score tests for association between traits and haplotypes when linkage phase is ambiguous. Am J Hum Genet 2002, 70:425-434.

28. Mackay AG, Urruticoechea A, Dixon JM, Dexter T, Fenwick K, Ashworth A, Drury S, Larionov A, Young O, White S, Miller WR, Evans DB, Dowsett M: Molecular response to aromatase inhibitor treatment in primary breast cancer. Breast Cancer Res 2007, 9:R37.

29. Schaid DJ: Mayo Clinic Research. [http://mayore search.mayo.edu/mayo/research/biostat/schaid.cfm]

30. Chanock SJ, Manolio T, Boehnke M, Boerwinkle E, Hunter DJ, Thomas G, Hirschhorn JN, Abecasis G, Altshuler D, Bailey-Wilson JE, Brooks LD, Cardon LR, Daly M, Donnelly P, Fraumeni JF Jr, Freimer NB, Gerhard DS, Gunter C, Guttmacher AE, Guyer MS, Harris EL, Hoh J, Hoover R, Kong CA, Merikangas KR, Morton CC, Palmer LJ, Phimister EG, Rice JP, Roberts J, et al.: Replicating genotypephenotype associations. Nature 2007, 447:655-660.

31. Cancer Genetic Markers of Susceptibility [https://caintegra tor.nci.nih.gov/cgems/]

32. Hunter DJ, Kraft P, Jacobs KB, Cox DG, Yeager M, Hankinson SE, Wacholder S, Wang Z, Welch R, Hutchinson A, Wang J, Yu K, Chatterjee N, Orr N, Willett WC, Colditz GA, Ziegler RG, Berg CD, Buys SS, McCarty CA, Feigelson HS, Calle EE, Thun MJ, Hayes RB, Tucker M, Gerhard DS, Fraumeni JF Jr, Hoover RN, Thomas G, Chanock SJ: A genome-wide association study identifies alleles in FGFR2 associated with risk of sporadic postmenopausal breast cancer. Nat Genet 2007, 39:870-874.

33. Eliassen AH, Missmer SA, Tworoger SS, Hankinson SE: Circulating 2-hydroxy- and 16 $\alpha$-hydroxy estrone levels and risk of breast cancer among postmenopausal women. Cancer Epidemiol Biomarkers Prev 2008, 17:2029-2035.

34. Goode EL, Pharoah PDP, Dunning AM, Wareham NJ, Ponder BAJ, Easton $D$ : No evidence for population substructure within the EPIC-Norfolk cohort [abstract]. AACR Meeting Abstracts 2005, \#4066:959.

35. Ries LAG, Krapcho M, Mariotto A, Miller BA, Feuer EJ, Clegg L, Horner MJ, Howlader N, Eisner MP, Reichman M, Edwards BK, Eds: SEER Cancer Statistics Review, 1975-2004. [http:// seer.cancer.gov/csr/1975 2004/]. Bethesda, MD: National Cancer Institute 